\title{
農作物の栽培を想定した 世界のバイオ燃料ポテンシャルの推定 MODELING WORLD BIOENERGY CROP POTENTIAL
}

\author{
萩原健介 $^{1} \cdot$ 花崎直太 ${ }^{2} \cdot$ 鼎信次郎 $^{3}$
}

Kensuke HAGIWARA， Naota HANASAKI， Shinjiro KANAE

\author{
1 学生会員 東京工業大学大学院理工学研究科土木工学専攻 学生（†152-8552 東京都目黒区大岡山 2-12-1） \\ 2 正会員 工博 国立環境研究所 研究員（†305-0051 茨城県つくば市小野川 16-2） \\ 3 正会員 工博 東京工業大学大学院情報理工学研究科情報環境学専攻 准教授（广152-8552 東京都目黒区大岡山 2-12-1）
}

\begin{abstract}
Bioenergy is regarded as clean energy due to its characteristics and expected to be a new support of world energy demand, but there are few integrated assessments of the potential of bioenergy considering sustainable land use. We estimated the global bioenergy potential with an integrated global water resources model, the H08. It can simulate the crop yields on global-scale at a spatial resolution of $0.5 \times 0.5$. Seven major crops in the world were considered; namely, maize, sugar beet, sugar cane, soybean, rapeseed, rice, and wheat, of which the first 5 are commonly used to produce biofuel now. Three different land-cover types were chosen as potential area for cultivation of biofuel-producing crop: fallow land, grassland, and portion of forests (excluding areas sensitive for biodiversity such as frontier forest). We attempted to estimate the maximum global bioenergy potential and it was estimated to be 1120EJ. Bioenergy potential depends on land-use limitations for the protection of bio-diversity and security of food. In another condition which assumed more land-use limitations, bioenergy potential was estimated to be $70 \sim 233 \mathrm{EJ}$.
\end{abstract}

Key Words : energy crop, global water resources model:H08, land-use limitation

\section{1. はじめに}

バイオ燃料とは，エネルギーや工業原料の資源として みた生物体量（バイオマス）のことを指し，バイオ然料 を化学反応させて得られたエネルギーはバイオエネルギ 一と呼ばれる. バイ才然料は主に植物から作られ，本研 究ではバイオ燃料の原料となる作物のことを『バイオ然 料作物』と呼ぶことにする. バイオ燃料のメリットは大 きく分けて 3 つあり, 1 つ目は再生可能エネルギーである こと. 2 つ目は二酸化炭素排出削減効果があること. そし て 3 つ目は地球規模で原料が広く分布しており，石油の ような「地政学的リスク」を回避できることである ${ }^{1)} .2030$ 年の世界の一次消費エネルギーの需要は 2007 年比で 40\%増加すると予想され ${ }^{2)}$, 加えて将来的な化石然料の枯 渇への懸念や温室効果ガスの排出削減といった関心から, これらのメリットを持つバイオ然料に多くの期待がかけ られた.しかし, バイオ然料作物の栽培には懸念が伴う。 バイオ燃料の生産拡大は, 限りある土地・水資源をめぐ る食糧との競合, 農地拡大に伴う生態系の破壊, 水資源
の枯渇といった事態を引き起こす可能性がある ${ }^{3)}$. そのた め事態を悪化させないためにも,「バイオ燃料はどの程度, 世界のエネルギ一需要を満たすことができ，導入に值す るのかどうか」という問いに対する答えが早急に求めら れているが，その研究が十分に行われていないのが現状 である ${ }^{4)}$. そこで上記の問いに答えるべく，世界の地上で どれほどのバイオ然料作物が栽培できるかという可能栽 培量を算出し，世界のバイオ燃料ポテンシャルを推定す ることが求められている.

本研究ではバイオ然料ポテンシャルを『あるバイオマ スから得ることのできるエネルギーの物理的な上限』と 定義する. 従って，バイオ然料をバイオエタノール等に 転換する際の転換効率は含まれない。また本研究では,

「この地域はこの作物を植えなければならない」といっ た政策的側面による土地利用の制約を受けず，『世界中ど のような種類の作物の栽培を想定しても良い』と仮定す る. このバイオ燃料ポテンシャルの定義は過去の研究に おいても用いられており ${ }^{3}$, 本研究もこの定義を用いるこ とによって過去の結果と比較することができる. 本研究 
では，作物の収穫部分（実際に食べる部分に相当）と収 穫部分以外（以下，残余）の一部をバイオ燃料として利 用することを想定しており (後述), 収穫部分と残余を合 わせたバイオマスが有しているポテンシャルをバイオ燃 料ポテンシャルと表現する. また残余が有しているポテ ンシャルを残余ポテンシャルと表現する. ポテンシャル を算定対象とした理由であるが，バイオ燃料から得るこ とのできるエネルギーの上限を求めることができること に加え, バイオ燃料はその利用方法が多岐に及び, エネ ルギーを得る際の技術レベルには地域差があるためであ る.これら地域によって様々に変わる要素を各々考慮し てバイオ燃料の評価を行うのは非常に困難であるため, ポテンシャルを算定して, バイオ燃料の評価を行う.

従来の研究では,「バイオ燃料作物のための農地面積」 と「単位面積あたりに見込める植物の平均的収量」の二 つからバイオ燃料ポテンシャルを求めるという推定の方 法をとってきた ${ }^{5)}$ (結果:約 277EJ). しかし，この方法で は「どの場所にどれだけのポテンシャルがあるのか」と いう空間的な評価に難があり，現在耕作地でない土地に バイオ燃料作物を栽培した場合に，気候条件等の影響を 踏まえて, どの程度の収量が得られるのか言及寸ること が困難である。これに対して，全球植物（作物）生長モ デルを用いることで空間的解析を行った既存の研究とし ては Campbell et al. (2008） の) と WBGU（2008） 3)がある. 食糧との競合が起こりにくいという理由から, Campbell et al.は放棄された農作地・牧草地において, WBGU は耕作 地や森林，生態系にとって重要な土地を除いた地域での 栽培を想定しており, 両者とも持続可能性を考慮して, 土地利用の条件を設定している. バイオ燃料作物に関し ては, Campbell et al.は特定の作物の作付けを想定せず, 自然植生によって得られるバイオマス量を採用し，現在 のバイオ燃料ポテンシャルを 32〜41EJ と算出し, WBGU は, バイオ燃料作物に生産性の高い牧草とユーカリやポ プラなど成熟までの期間が短い木を採用し，現在のバイ オ然料ポテンシャルを 34〜120EJ と算出した. これらの 結果は現在の一次消費エネルギーの $7.5 〜 25 \%$ に相当する. しかし過去の研究の推定值にはまだまだ幅があり, これ

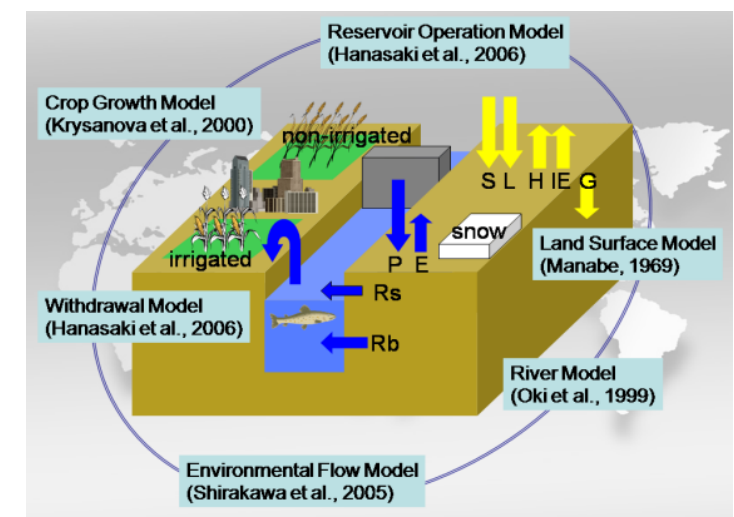

図-1 全球統合水資源モデルの 6 つのサブモデルの概略図
は Campbell et al. ${ }^{6}$ やWBGU ${ }^{3)}$ がそれぞれ特定の条件下で 計算を行っているのが大きな要因である. そのため一つ や二つの推定值だけ存在寸れば事足りるわけではなく, 様々な条件の下での推定值の比較を行い, ぞの要素が大 きな影響を与えているのかを明らかにすることに深い意 義がある.また，食料との競合・生態系の保全・水資源 について言及し，バイオ然料の持続可能性を追求するの が我々の最終的な目標であり，そのためには他のチーム の結果を待つのではなく, 自分たちのツールで計算を始 める必要がある. そこで本研究は最終的な目標の第一歩 として，独自に設定した条件の下で，我々が開発中であ る全球統合水資源モデル：H08 燃料ポテンシャルの推定を行うことを目的とする.

\section{2. 手法}

\section{（1）全球統合水資源モデル : H08}

全球バイオ然料ポテンシャルを推定する上で重要な点 は「どこでどれだけ得られるのか」という空間的な評価 を行うことである，そこで本研究では，空間的評価を可 能とするために，全球スケールで自然・人為起源の水循 環と作物成長を同時に扱うことのできる，全球統合水資 源モデル 7.8)（以下，H08）を用いた. H08 は陸面過程, 河川, 作物, 貯水池操作, 環境用水, 取水の 6 つのサブ モデルから構成され，それぞれを組み合わせて利用され る（図 1 は 6 つのサブモデルを組み合わせて利用した際 の概略図である)。このモデルの特徴は，作物成長モデル が組み込まれている点と, 土地利用において灌激農地と 非灌溉農地の分割を行っている点である. 気象情報と土 地利用の情報を与えると, 自然の水循環に加えて, 貯水 池操作や農業・工業・生活などの取水といった人間活動 による影響も考慮した水循環を，全球スケールの日単位 のタイムステップで計算することができる. H08 の数值 実験の設定条件は Hanasaki et al. (2010) ${ }^{8)}$ の結果を利用し た．その設定条件を表 1 にまとめる.

表-1 数值実験の設定条件 (Hanasaki et al. (2010) より)

\begin{tabular}{ll}
\hline 入カデータ & Reference \\
\hline \hline Spatial domain/resolution & Global, $0.5^{\circ} \times 0.5^{\circ}$ \\
Temporal domain/resolution & $1980-1999,6 \mathrm{~h}$ \\
Meteorological forcing & NCC (Ngo-Due et al., 2005) \\
Land cover & \\
Albedo & ISLSCP2 (Hall et al., 2006) \\
Vegetation & Not specified \\
Soil & Not specified \\
Cropland & Ramankutty et al. (2008) \\
Irrigated cropland & Siebert et al. (2008) \\
Crop type & Monfreda et al. (2008) \\
\hline
\end{tabular}


バイオ燃料ポテンシャルを求めるために重要なサブモ デルは作物成長モデルで，このモデルは作付け種，作付 け開始日，作付け期間中の気象データ，土壤・施肥・管 理情報（灌湐の有無）などの入力に対し，収穫日，総生 物体量収量, 蒸発散量などの出力を $0.5^{\circ} \times 0.5^{\circ}$ の空間解像 度で返す. 本研究ではこれらの出力の 1 つである収量デ 一タを利用した．また，ポテンシャル量の推定が目的な ので，H08 において土壌の栄養不足によるストレスがか からない設定とし，世界中で十分な土壤の栄養があると 仮定した.

\section{（2）バイオ燃料作物の選択}

先行研究において Campbell et al は自然植生によるバイ オマスを, 農作物に比べて得られる収量が大きいという 理由からバイオ然料作物として想定している ${ }^{\circ}$. WBGU は成長の早い 2 種類の木本と 1 種類の生産性の高い牧草 を植えることを想定している ${ }^{3}$. しかし，これらは得られ るエネルギーが大きいという面から見た場合において理 想的だと思われる作物である. バイオ燃料作物を大規模 に栽培するとなると，作物の病気・経済的・社会的等の 様々な要因が関わるため, 実社会において上記の作物が バイオ燃料として選択されるとは限らず，他の作物につ いても議論の余地がある. そこで本研究では H08 が作物 成長を再現可能な作付け種の中で，すでにバイオ燃料と して栽培されている作物（アブラナ・サトウキビ・ダイ ズ・テンサイ・トウモロコシ）に，世界で広く栽培され ている作物（コムギ・コメ）を加えた 7 種類をバイ才然 料作物とした. H08 においてこれら 7 種の作物の作付け を各グリッドで行い，ポテンシャルを求めるため一番大 きい収量が得られる作物がグリッド内に一様に植えられ ていると仮定した。 しかし，すべての陸地から作物の収 量が得られるわけではない. H08 の作物成長モデルにお いて，作物がどれだけ成長するかは，主として気温と土 壤水分量によって決まるため, 土㗒水分量が少ない場合, そのぶん収量も少なくなる，そのため，砂漠など水資源 に乏しい乾燥地域では，収量はほとんど得られない．

今回はポテンシャルを求めることが目的なので，上記 の各作物の, アメリカの収量とアメリカと同じ栽培地で の H08 の収量が合うように, H08 の収量の補正を行った. H08 の作物成長モデルは作物の各々に固有のパラメータ 群が設定されているが，それらの值は全球で一律となっ ているため, モデルの出力する収量はこの補正によって, アメリカと同水準，言い換えると先進国と同水準の農業 技術を用いた栽培を，それぞれの国の気象条件の元で行 った場合の収量と仮定できる. そのため, 実際の収量と 比較すると発展途上国では収量が大きくなる傾向がある ことに注意が必要である. 水分を多く含むサトウキビと テンサイは，バイオ燃料ポテンシャルを求める際にその 影響が無視できないので, 乾物収量を用いて補正した.
コメ・コムギ・ダイズ・トウモロコシの収量の補正には USDA，(1994）の統計值を用い, アブラナにはFAOSTAT, （1988～92）の統計值を用いた. サトウキビ・テンサイ の乾燥収量は Murata，(1981） 9)の值を用いた.

\section{（3）残余の利用について}

植物の実を取り除いた茎，葉，根などの残余の利用は 食料との競合を起こしにくいとされる ${ }^{3}$. 茎, 葉, 根など の細胞組織はセルロースを主成分とする堅い細胞壁で覆 われているため，現段階では残余をバイオエタノール等 の液体燃料に転換するのが困難であるが，液体燃料一の 容易な転換のための研究が盛んに行われており，近い将 来，セルロース系由来のバイオ燃料が登場することは十 分考えられる. また残余を燃やしてエネルギ一を取り出 すのであれば，細胞壁の問題は解決できる，一方で収穫 後の畑から残余を取り除くことは，土㙵の栄養や雨風に よる浸食の観点から問題であるとの指摘も多く，過去の 研究において，残余を $20 \sim 30 \%$ 以上取り除いてしまうと 風や雨による浸食が起こり $25 \%$ 以上取り除くと土畩の有 機物の減少が報告されている ${ }^{10)}$ ，そこで本研究では残余 の $25 \%$ \%たバイオ燃料に転用することにする。 なお，

WBGUは地上バイオマスの $90 \%$ を利用し ${ }^{3}$, Campbell et al. はバイオマスの $50 \%$ が地上バイオマスと仮定し，その地 上バイオマスをバイオ燃料に利用するとしているの.

また，十分な土壤の栄養と水が想定できるアメリカの フロリダ州において, WBGU の想定した木本や草の収量 と本研究の収量の比較を行うと, WBUG が木本・草とも に 45〜55 [t/ha] 程度であるのに対して ${ }^{3)}$, 本研究が想定し た 7 種の作物うち, 残余も含めた収量が最大となる作物 では 35〜 50 [t/ha] 程度であるので, 収量の違いは 1 2 割 程度であり，栽培作物の違いによる影響はそれほど大き くないといえる.

\section{3. バイオ燃料作物の栽培地}

\section{（1）パイオ燃料作物の栽培地の選択}

バイオ燃料作物の栽培地の選択にあたって，オースト リアの Klagenfurt University が作成した全球土地利用デー タセット (A comprehensive global $5 \mathrm{~min}$ resolution land-use data set for the year 2000 consistent with national census data ) を用いた．衛星データを用いて，全球の陸地の土地利用 を Infrastructure area，Cropland，Forestry，Non-used area, Grazing land の 5 つに分け，統計值と整合性を合わせた土 地利用データである. Non-used area とは，山の頂上や荒 れ地，砂漠，氷床など作物の栽培に適さない地域や人間 の手が及んでいない地域であり, Grazing land はその他の 4 つの土地利用に含まれない土地である.これらの各土地 利用についてバイオ燃料作物の栽培地になり得るかどう かを検討することで，地球上すべての土地について言及 
することができる. Infrastructure area と Non-used area には 栽培不可なので残る 3 つの土地利用について考える. ま ずは Cropland であるが，食糧との土地利用の競合を防ぐ ために，バイオ燃料作物の栽培は行わない，ただし休耕 地はバイオ燃料の栽培地として利用可能で，Cropland か ら得られる残余もその $25 \%$ だけバイオ燃料として利用で きるとした. Grazing landについては，放牧との土地利用 の競合を防ぐために牧草地は除き, 残る草地で栽培する. Forestry に関しては, 生態系保護のため原生林や保護区を 除き，残った森林の一部をジャトロファなどのバイオ燃 料用植物の栽培地に転用寸る. 以上より（i ）休耕地（ii） 牧草地を除いた草地（iii）生態系保護のため原生林や保 護区を除いた森林の一部，をバイオ燃料作物の栽培地と した．それぞれの栽培地について順を追って説明してゆ く.なお，以下に登場する各土地利用データの対象年度 が一致していないが，その影響は無視できる程度である.

\section{（2）休耕地}

農地の面積に関する各国のデータは FAOSTAT が公開 しており，休耕地の面積は'fallow land'で表される. しか し，すべての国において休耕地の土地面積を公開してい るわけではなく，世界中の休耕地面積のデータが得られ ない，そこで川島（2008）の中の『FAOSTAT が同じく公 開している, 耕作地面積 (arable land) と収穫面積 (harvested area）の差を便宜上休耕地とする』 ${ }^{11)}$ という算定法を用い て休耕地の面積を求めることにした。 二期作を行ってい る国の場合, 収穫面積はその分増加するので, Döll and Siebert $(2002)^{12)}$ の世界の 19 地域における作付け回数」 を用いて個別に求めた. 表 2 はその具体的な作付け回数 である. 収穫面積を作付け回数で割ることによって，一 回作付けした際の収穫面積を求めることができ, 求まっ た一回分の収穫面積を arable land の面積から引いて休耕

\begin{tabular}{ll|ll}
\multicolumn{4}{c}{ 表-2 世界の 19 地域における作付け回数 } \\
\hline 地域 & $\begin{array}{l}\text { 作付け } \\
\text { 回数 }\end{array}$ & 地域 & $\begin{array}{l}\text { 作付け } \\
\text { 回数 }\end{array}$ \\
\hline \hline Canada & 1.0 & Eastern Europe & 1.0 \\
United States & 1.0 & Baltic States, Belarus & 0.8 \\
Central America & 1.0 & Rest of former USSR & 0.8 \\
South America & 1.0 & OECD Europe North & 1.0 \\
Northern Africa & 1.0 & OECD Europe South & 1.0 \\
Western Africa & 1.5 & East Asia & 1.5 \\
Eastern Africa & 1.0 & South East Asia & 1.2 \\
Southern Africa & 1.0 & South Asia & 1.3 \\
Japan & 1.5 & Middle East & 1.0 \\
Oceania & 1.5 & & \\
\hline
\end{tabular}

地の面積を求めた. その際, 休耕地面積が負となった国 は除外した. 収穫面積と農地面積のデータは FAOSTAT の 2007 年のものを用いた.

今回本研究が算定した 2007 年の休耕地の面積と, FAO が休耕地面積 fallow land'を公開している国に関して，そ の面積の比較を行うと（公開されているデータが限られ ているため，比較年度が合わない場合があるが，数年で 休耕地が倍以上変わることは無いと思われるので，その 影響は無視できるとした), アメリカでは, 本研究が 7355 万 ha であるのに対し, FAO の 2002 年のデータでは 1690 万 ha と約 4.4 倍大きく見積もり，フランス（FAO 2007） においては 5 倍, ドイツ (FAO 2007) においては 4.3 倍 ほど大きく見積もっている，一方インドの場合，本研究 が 2375 万 ha であるのに対し，FAO の 2005 年の データ では 2471 万 ha とほぼ等しい，また二期作を行っている 国に関しては，休耕地面積が小さく見積もられる傾向に ある．世界全体では休耕地面積を大きく見積もる傾向に あり，それを考慮すると，休耕地から得られるバイオ燃 料ポテンシャルは大きく見積もられた值であるといえる.

\section{（3）牧草地を除いた草地}

牧草地のデータには Agricultural Lands in the Year 2000 M3-Pasture Data (Ramankutty, 2008) を用いた. Grazing land からこの牧草地を除いた残りの草地において，バイオ燃 料作物の栽培を想定する.

\section{（4）生態系保護のため原生林や保護区を除いた森林の一 部}

原生林には World Resources Institute（WRI）が提唱して いる Frontier forest のデータを, 保護区には World Database on Protected Areas (WDPA) が提供している Reserved area のデータを用い，これらの土地を Forestry から除いた. ただしこれらの土地を除外することで生態系が十分に守 られるわけではない. 残った森林面積の一部にアブラヤ シやジャトロファなどのバイオ燃料用植物の栽培地に転 用することし，その転用率は $10 \%$ とした．また，アブラ ヤシやジャトロファの収量は 12 [dry-t/ha] を用いた.

\section{(5) パイオ燃料ポテンシャル推定ための計算条件}

本研究では陸上における世界のバイオ然料ポテンシャ ルの推定において以下の 2 つケースを想定する.

$$
\text { ケース } 1 \text { では，この章の（2）〜（4）で述べた } 3 \text { つの }
$$
土地においてバイオ燃料の栽培を想定した際のポテンシ ヤル量の推定を行う.ケース 2 では, 先行研究である WBGU とできる限り同じ栽培地条件でバイオ燃料を栽培 した際のポテンシャル量の推定を行う．WBGU は耕作地 や生態系にとって重要な地域, 炭素の貯蔵庫である森林 を除き，残る土地の中で生態系の保全の程度を幾つか変 えて, バイオ燃料の栽培を想定しており ${ }^{3)}$, 本研究では 
WBGU の栽培条件とできる限り同じ条件 (生態系の保全 に関する条件が最も緩い 100～120EJ の場合）で計算を行 うため, 草地での栽培を想定し, 劣化土㙥による影響を 考慮した. 劣化土壌のデータは Global Assessment of Human-Induced Soil Degradation（GLASOD）を用い，その劣 化土壤の影響には, WBGU と同様の条件 (GLASOD の カテゴリー3では収量が 30\%になる）を用いた ${ }^{3)}$. 入手す ることができなかった土地利用データが存在するため, 栽培地は完全に一致せず, 推定値には幅が存在する.

ケース 1 では, 耕作地や保護区など人類や生態系にと って最低限必要だと思われる土地を除いた土地において, 可能な限りバイオ燃料の栽培を想定しており, さらに土 壌も十分な栄養を仮定しているので，推定されるバイオ 燃料ポテンシャルは最大值に限りなく近い. しかしその 推定量がごく僅かであれば, バイオ燃料の導入に有効性 はないということになる，そのため，地上にどれほどの バイオ燃料ポテンシャルが存在し, どの程度エネルギー 需要を満たすのか評価するのがケース 1 の目的である. 土壤に十分な栄養を仮定したのも, バイオ燃料ポテンシ ヤルの最大值を求めるためである. 今後, H08 の作物生 長モデルに, 土壤の栄養が作物収量に与える影響を追加 し, 土壤の栄養がバイオ燃料ポテンシャルにどの程度影 響を及ぼすのかを評価する必要がある。

ケース 2 は, ポテンシャル量の推定を行う際に大きく 影響を及ぼすのは，モデルの違いなのか栽培地条件の違 いなのかについて, 結果同士を比較・検討することで明 らかにするのが目的である. 両ケースの違いは, ケース 2 の方がケース 1 より多くの土地を生態系のために保護し, 主なバイオ然料の栽培地が劣化土㙵である点である.

\section{4. 結果 · 考察}

ケース $1 \cdot$ ケース 2 における結果およひ現在の一次消費 エネルギーを表 3 にまとめた. ケース 1 に関して，現在 の一次消費エネルギーが 467EJ であるのに対し，世界の バイオ燃料ポテンシャルはその 2.4 倍の $1120 \mathrm{EJ}$ （残余 256EJ）にのぼり, 過去 2 つの研究に比べると 4 33 倍と 本研究の推定值は遙かに大きい值である. アメリカ・中 国・ヨーロッパを除く国と地域において, バイオ燃料ポ テンシャルが一次消費エネルギーを上回り，特にアフリ カ大陸には多くのバイオ燃料ポテンシャルが存在するこ とを示寸結果となった．自国の一次消費エネルギーが多 いため, アメリカ・中国ではエネルギー比が 1 を下回っ ているが, 有しているバイオ燃料ポテンシャルは大きい. バイオ燃料ポテンシャルの内訳を見ると，ほとんどの 国・地域において草地が一番のバイオ燃料の供給源とな っており，とりわけアメリカ大陸とアフリカ大陸は草地 から得られるポテンシャル量が大きい. 図 2 は草地から 得ることのできるバイオ燃料ポテンシャルについて示し た図で，色が赤くなるほど大きなポテンシャルを意味し ているが，高いポテンシャルを示している地域はエチオ ピアやアルゼンチンの高地, アフリカのサバンナである. これは本研究が想定した草地には高地や急峻な斜面, サ バンナなどの地域が含まれ，気象条件さえそろえばバイ 才燃料が得られるためである. 加えて, H08 の作物成長 モデルにおいて，世界中で先進国と同水準の栽培が行わ れていると仮定したこともポテンシャル量が大きくなっ た要因であると考えられる. また，残余ポテンシャルは 世界全体で約 256EJ あると推定され, 残余ポテンシャル

表-3 ケース 1 およびケースにおける, 各大陸·国のバイオ燃料ポテンシャル. ケース 1 に関しては各地域の一次消費エネルギーおよ びバイオ燃料ポテンシャルとのエネルギー比が示し, さらにはバイオ燃料ポテンシャルに関しては 3 つの栽培地の内訳が示して ある. なお, 農地から得られる残余のバイオ燃料ポテンシャルは休耕地に含まれ, 本研究ではバイオマスの持つエネルギ一量に 18. 6GJ/Mg を用いた. 一次消費エネルギーはWor Id Energy Outlook, 2009 の 2009 年の值である2゙.

\begin{tabular}{|c|c|c|c|c|c|c|c|}
\hline \multicolumn{7}{|c|}{ ケース 1} & \multirow{3}{*}{$\begin{array}{c}\text { ケース } 2 \\
\text { バイオ燃料 } \\
\text { ポテンシャル } \\
(\mathrm{EJ})\end{array}$} \\
\hline \multirow[t]{2}{*}{ 地域・国名 } & \multirow{2}{*}{$\begin{array}{c}\mathrm{A}: \text { 一次消費 } \\
\text { エネルギー } \\
\text { (EJ) }\end{array}$} & \multirow{2}{*}{$\begin{array}{c}\mathrm{B} \text { : バイオ燃料 } \\
\text { ポテンシャル } \\
\text { (EJ) }\end{array}$} & \multicolumn{3}{|c|}{ バイオ燃料ポテンシャルの内訳 (EJ) } & \multirow{2}{*}{$\begin{array}{c}\text { エネルギー比 } \\
\mathrm{B} / \mathrm{A}\end{array}$} & \\
\hline & & & 休耕地 & 草地 & 森林 10\% & & \\
\hline オセアニア & 5.78 & 44.6 & 11.3 & 30.8 & 2.48 & 7.72 & $1.23 \sim 4.95$ \\
\hline ヨーロッパ & 116 & 97.4 & 42.8 & 34.9 & 19.7 & 0.84 & $13.1 \sim 35.1$ \\
\hline アメリカ & 91.4 & 88.8 & 41.2 & 41.9 & 5.7 & 0.97 & $9.23 \sim 25.6$ \\
\hline ブラジル & 9.45 & 69.7 & 3.19 & 56.3 & 10.2 & 7.38 & $4.48 \sim 24.8$ \\
\hline アメリカ大陸 & 135 & 332 & 77.0 & 226 & 29.3 & 2.46 & $22.6 \sim 79.0$ \\
\hline インド & 19.6 & 42.3 & 16.1 & 24.8 & 1.40 & 2.16 & $6.85 \sim 19.9$ \\
\hline 中国 & 91.2 & 84.4 & 27.8 & 53.0 & 3.63 & 0.92 & $8.01 \sim 22.1$ \\
\hline アジア & 168 & 241 & 65.2 & 164 & 11.7 & 1.43 & $18.0 \sim 61.6$ \\
\hline アフリカ大陸 & 15.1 & 405 & 77.6 & 314 & 12.9 & 26.8 & $14.0 \sim 51.5$ \\
\hline 世界合計 & 467 & 1120 & 274 & 770 & 76.1 & 2.40 & $70 \sim 223$ \\
\hline
\end{tabular}




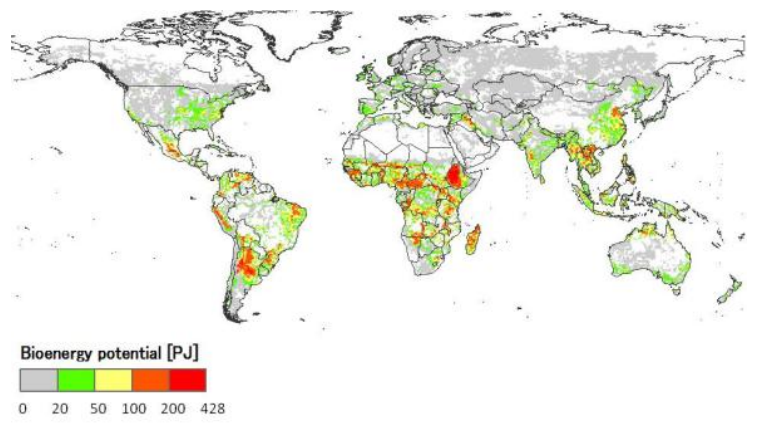

図- 2 草地から得ることのできるバイオ燃料ポテンシャル (ケース 1). 赫い色ほど得られるエネルギ一が大きい. だけで現在の一次エネルギーの約 55\%に相当する. 残余 のみの利用でこれだけのエネルギーが得られるというこ とは，食料との競合を考慮すると重要な意味を持つ.

ケース 2 において，世界のバイオ然料ポテンシャルは 70〜233EJ と推定され, WBGU の 100〜120EJ と近い值と なった. ケース 1 とケース 2 の推定值の差 $(887$ 1050EJ) の主な要因が, 栽培地面積の違いなのか, 劣化土壌の影 響（GLASOD のカテゴリー3 では収量が 30\%になる）に よるものなのかを明らかにすると，786～1023EJ（約 90\% 以上）が栽培地面積の変化による影響であり，劣化土壤 を考慮した事による影響は 27～101EJ（約 10\%以下）で ある. 両ケースの推定值の差のほとんどが, 栽培地面積 の違いに起因している. 栽培地面積の違いは，可能な限 りの土地でバイオ然料作物の栽培を想定したケース 1 に 対し，ケース 2 が，生態系保全を優先し，バイオ燃料作 物を栽培しても生態系にとって差し支えないと思われる 土地のみでの栽培を想定するという，保守的な条件であ ることから生じている.

WBGU とは異なるモデルを用いながらも，栽培地条件 をほぼ同じにすることで, 推定值が WBGU の值と近い值 となるという結果から, バイオ燃料ポテンシャルの推定 における不確実性の幅は, 栽培地面積に大きく依存して おり, 両ケースの推定值が大きく異なるのも，過去の研 究結果と比較して本研究の結果が大きいのも, 栽培地条 件の違いによる影響が大きい. 一方で，モデルの違いに よる影響は相対的に小さい. また，用いた土地利用デー タの不確実性が今回の推定值に大きく影響を及ぼしてい る可能性を示唆する結果ともいえる.

\section{5. まとめ}

本研究は世界のバイオ燃料ポテンシャルの推定を行っ たものである. アブラナ・サトウキビ・ダイズ・テンサ イ・トウモロコシ・コムギ・コメの 7 種類バイオ然料作 物として想定し，その収量は全球統合水資源モデル: H08 を用いて再現した。 バイオ然料作物の栽培地には（i ） 休耕地（ii）牧草地を除いた草地（iii）生態系保護のた
め原生林や保護区を除いた森林の一部を選んだ。その結 果, 世界のバイオ然料ポテンシャルを $1120 \mathrm{EJ}$ と推定した.

過去の研究結果とできる限りの同じ条件のもとでの世 界のバイオ燃料ポテンシャルの推定も行い，バイオ然料 ポテンシャルの推定を行う際に大きく影響を及ぼす要因 は，モデルの違いなのか栽培地条件の違いなのかを明ら かにすることを試みた。その結果，過去の研究結果に近 い推定值となり，世界のバイオ然料ポテンシャルの推定 には，栽培地に大きく影響し，モデルの違いによる影響 は相対的に小さいことが分かった。

謝辞：研究は CREST『世界の持続可能な水利用の長期ビジョン 作成』（代表 : 鼎 信次郎）の成果の一部である.ここに記して 深く謝意を表します.

\section{参考文献}

1) 小泉達治.バイオエタノールと世界の食糧需給, 筑波書房 (2007), pp15-88

2) IEA. World Energy Outlook, 2009

3) German Advisory Council on Global Change (WBGU), Future Bioenergy and Sustainable Land Use, (2008), pp95-131.

4) Robertson, G.P., et al., Sustainable Biofuels Redux, Science 3 October (2008), pp49-50.

5) Yamamoto, H., Fujino, J. and Yamaji, K., Evaluation of bioenergy with a multi-regional global-land-use-and-energy model. Biomass and Bioenergy, 20, (2001), pp151-159.

6) Campbell, J.E., Lobell, D.B., Genova, R.C. and Field, C.B., The Global potential of Bioenergy on Abandoned Agriculture Lands, Environmental Science \& Technology, 42, (2008), pp5791-5794.

7) Hanasaki, N., Kanae, S., Oki, T., et al., An integrated model for the assessment of global water resources - Part 1: Model description and input meteorological forcing, Hydrology and Earth System Sciences, 12, (2008), pp1007-1025.

8) Hanasaki, N., Inuzuka, T., Kanae, S. and Oki, T., An estimation of global virtual water flow and sources of water withdraw for major crops and livestock products using a global hydrological model, Journal of Hydrology, 384, (2010), pp232-244.

9) Murata,Y., Dependence of potential Productivity and Efficiency for Solar Energy Utilization on Leaf Photosynthetic Capacity in crop Species, The Crop Science of Japan, 50, (1981), pp223-232.

10) Lal, R. Crop residues as soil amendments and feedstock for bioethanol production, Waste Management, 28, (2008), pp747-758.

11）川島博之. 世界の食糧生産とバイオマスエネルギー2050 年 の展望, (2008), pp10-13.

12) Döll, $P$ and Siebert, $S$. Global modeling of irrigation water requirements, WATER RESOURCES RESEARCH, 38, 4, (2002), pp8-1 8-10.

(2010. 9. 30 受付) 